\title{
Maximizing the diagnostic information from biopsies in chronic inflammatory bowel diseases: recommendations from the Erlangen International Consensus Conference on Inflammatory Bowel Diseases and presentation of the IBD-DCA score as a proposal for a new index for histologic activity assessment in ulcerative colitis and Crohn's disease
}

\author{
Corinna Lang-Schwarz ${ }^{1}$ Abbas Agaimy ${ }^{2} \cdot$ Raja Atreya $^{3,4} \cdot$ Christoph Becker $^{3,4} \cdot$ Silvio Danese $^{5}$ - Jean- \\ François Fléjou ${ }^{6}$. Nikolaus Gaßler ${ }^{7} \cdot$ Heike I. Grabsch ${ }^{8,9} \cdot$ Arndt Hartmann $^{2} \cdot$ Kateřina Kamarádová $^{10}$. \\ Anja A. Kühl ${ }^{4,11}$ - Gregory Y. Lauwers ${ }^{12}$ - Alessandro Lugli ${ }^{13} \cdot$ Iris Nagtegaal $^{14}$ - Markus F. Neurath ${ }^{3,4}$. \\ Georg Oberhuber ${ }^{15} \cdot$ Laurent Peyrin-Biroulet $^{16} \cdot$ Timo Rath $^{3} \cdot$ Robert Riddell $^{17} \cdot$ Carlos A. Rubio $^{18} \cdot$ Kieran Sheahan $^{19}$. \\ Herbert Tilg ${ }^{20}$. Vincenzo Villanacci ${ }^{21} \cdot$ Maria Westerhoff ${ }^{22} \cdot$ Michael Vieth $^{1,2}$
}

Received: 16 September 2020 / Revised: 13 November 2020 / Accepted: 1 December 2020 / Published online: 29 December 2020

(C) The Author(s) 2020

\section{Introduction}

Chronic idiopathic inflammatory bowel disease (IBD) cases are on the rise, with approximately 6.8 million people diagnosed in 2017 [1]. Diagnosing the two main forms of IBD, ulcerative colitis (UC) and Crohn's disease (CD), involves a combination of clinical history, laboratory findings, imaging, endoscopy and histology [2].

The histopathological diagnosis of IBD is based on a combination of microscopic findings, with consideration of clinical data that include the patient's age, symptoms, duration of symptoms and endoscopic results [3-17].

$\mathrm{CD}$ is a chronic, progressively destructive disease with an intermittent course in most cases. UC is most often described as relapsing and remitting, with symptoms of active disease that alternate with periods of clinical quiescence called remission $[18,19]$. Until recently, therapeutic strategies in both diseases aimed to achieve adequate control of gastrointestinal inflammation. In recent years, however, mucosal healing has become the key treatment goal in IBD. It is associated with improved clinical outcomes, prolonged remission, fewer hospitalizations and decreased probability for surgery [20-36]. Patients with

This article is part of the Topical Collection on Quality in Pathology

Michael Vieth

vieth.lkpathol@uni-bayreuth.de

Extended author information available on the last page of the article mucosal healing have lower rates of clinical relapse compared to those with evidence of active or quiescent disease. Endoscopic evaluation without histology, however, may be insufficient to deem treated IBD mucosa as completely healed $[34,36]$. Furthermore, histologic identification of active disease has also been shown to better predict the development of neoplasia in patients with UC compared to endoscopic assessment of activity [30-32, 34, 37]. The fact that concordance between endoscopic and histological remission is moderate only - with histological remission being superior-underscores the necessity of incorporating histologic methods of activity scoring into clinical trials [34]. In fact, in 2016, the Food and Drug Administration (FDA) of the United States Department of Health and Human Services recommended that histologic assessment be used in conjunction with endoscopy [38].

A number of histologic indices for assessing activity in UC and $\mathrm{CD}$ exist. Nevertheless, they all have limitations, including lack of full validation, difficulty of usage and heterogeneity in their standards for distinguishing between quiescent disease and histologic normalization [39, 40]. Moreover, there is also a need for standardization of biopsy procedures in UC and $\mathrm{CD}$ on the endoscopic end.

Recommendations for biopsy procedures and IBD scoring exist from many internationally recognized organizations, such as the European Crohn's and Colitis Organisation (ECCO), the World Gastroenterology Organisation (WGO), the British Society of Gastroenterology (BSG), the International Organization for the Study of Inflammatory 
Bowel Diseases (IOIBD), the American College of Gastroenterology (ACG) and the American Society for Gastrointestinal Endoscopy (ASGE). Some of them have recently been updated $[17,19,28,41-51]$.

However, in practice, these existing recommendations are not widely adhered to and there is still a need for standardizing the number of IBD biopsies, the locations they are taken from and an accepted validated IBD histologic assessment tool for daily practice.

For these reasons, the objectives of the 2020 International Consensus Conference on IBD Activity Scoring were (i) to review existing recommendations and to agree upon ten recommendations with the highest impact to maximize diagnostic information from biopsies for $\mathrm{UC}$ and $\mathrm{CD}$ and (ii) to agree on a simple, histologic scoring system for both types of IBD that is able to distinguish between quiescent disease and mucosal healing and has potential for use in daily routine practice as well as for clinical trials.

\section{Material and methods}

\section{Consensus process}

The meeting took place from the 8th to the 10th of January 2020 at the Institute of Pathology of the Friedrich-Alexander University in Erlangen, Germany, with participants from 12 countries. Six sessions comprising presentations, discussions and group microscopy sessions took place. The conference was followed by a validation process of the consensus-approved scoring index. This involved individual member evaluations of digitally scanned IBD biopsy slides.

\section{Steering committee and participants}

The steering committee (MN, AH and the chairman MV) organized the meeting in Erlangen. Twenty-seven participants with expertise in IBD from the USA, Canada and Europe were invited to attend the face-to-face meeting, and 25 agreed to participate (17 gastrointestinal pathologists, 6 gastroenterologists and two translational researchers). Five were unable to attend but participated in the post-meeting validation of the agreed-upon scoring system as well as the voting at final ballot according to a modified Delphi panel. All participants were voting members.

\section{Methodological exactness}

\section{Search strategy and sources of evidence}

The recommendations that reached consensus were based on peer-reviewed publications in addition to expert opinions, accepted practice standards and consensus. To obtain consensus, a two-round modified Delphi process was used. For this purpose, two rounds of systematic literature searches regarding IBD and activity scoring on PubMed, the Cochrane Library and EMBASE were performed. The first took place prior to the meeting and was circulated for review to all of the participants. At the end of the face-to-face meeting, a first voting round on the developed statements took place. Additional literature from a second literature search was added post-meeting using combinations of key words such as "IBD", "UC", "CD", "histopathology" and "activity". Six months postmeeting, a final anonymous Delphi questionnaire round took place. Participants were asked to review and reconsider their initial ratings for the developed statements on a circulated questionnaire using a 5 -point Likert scale $(5=$ agree $(100 \%)$, $4=$ partly agree $(75 \%), 3=$ neutral $(50 \%), 2=$ partly disagree $(25 \%), 1=$ disagree $(0 \%))[41,42]$. Strength of consensus was graded as follows: $<75 \%$, no consensus; $75-95 \%$, consensus; and $>95 \%$, strong consensus.

\section{Evidence levels and recommendation grades}

The literature was rated according to the evidence classification of the Oxford Centre for Evidence-based Medicine (OCEBM), using the 2011 version (supplemental Table 1) [52].

Evidence and recommendations from established clinical and pathological guidelines were also taken into account, including documents from the ECCO, the ASGE, the WGO, the ACG, the IOIBD, the Updated S3-Guideline of the German Society for Digestive and Metabolic Diseases (DGVS), the updated BSG guidelines and a practical guide on tissue pathways for gastrointestinal and hepatopancreatobiliary pathology $[2,41,43-51,53-55]$.

Evidence levels (ELs) and grades of the recommendations are given below where possible. In accordance with the OCEBM, recommendation grades are defined as the following: A, consistent level 1 studies; B, consistent level 2 or 3 studies or extrapolations from level 1 studies; C, level 4 studies of extrapolations from level 2 or 3 studies; and D, level 5 evidence or troublingly consistent or inclusive studies of any level.

The recommendations, rather than being rules, are intended to help endoscopists maximize the potential diagnostic information they can render from biopsies to optimize their patients' care. An overview of the consensus process is available as supplemental Fig. 1.

\section{Microscopy sessions}

Prior to the meeting, haematoxylin and eosin (H\&E)-stained slides of $59 \mathrm{UC}$ large bowel biopsy cases and $25 \mathrm{CD}$ biopsy sets from large bowel, terminal ileum and stomach were digitalized at the Institute of Pathology, Bayreuth, using the slide 
scanner NanoZoomer S360 (Hamamatsu, Herrsching am Ammersee, Germany). All participants had access to the slides prior to the meeting on a virtual, password-secured platform (software: NDP.view 2; Hamamatsu, Herrsching am Ammersee, Germany). Microscopy sessions during the faceto-face meeting allowed for group discussions of selected cases around a multi-headed microscope (Olympus BX53; Olympus, Hamburg, Germany).

\section{Presentations}

The conference presentations comprised the scientist's (CB), the clinician's (MN) and the pathologist's (MV) views concerning IBD activity scoring, along with their field-specific needs for an approved scoring system.

\section{Results and discussion}

\section{Recommendations}

An overview of the 10 recommendations that achieved consensus is shown in Table 1.

Recommendation 1 If colonoscopic biopsies are being taken for the diagnosis of chronic idiopathic IBD, the samples should be sent in separate, designated containers, particularly biopsies of the rectum (vote: strong consensus (95\%), level of evidence: $1 a-2 b$, recommendation grade: $B)$.
Evidence and decision When the initial diagnosis of IBD is suspected, current guidelines and consensus papers recommend an ileocolonoscopy with biopsies from the terminal ileum as well as from each colonic segment: caecum, ascending colon, transverse colon, descending colon, sigmoid and rectum $[2,19$, $43,45,46,56,57]$. Rather than pooling biopsies from multiple sites into the same container, the biopsies should be delivered to the pathologist in separate, designated containers. This assists in distinguishing between $\mathrm{UC}$ and $\mathrm{CD}$ and for properly evaluating the distribution of the disease $[2,4,43,53,56,58,59]$ (EL 2a$2 b)$. The importance of proper sampling and designating biopsy sites is exemplified in patients who exhibit unusual distribution of inflammation. Without clear designation of separate sites, it is challenging to diagnose $\mathrm{CD}$ in patients who lack terminal ileum involvement, or UC in patients who have proctitis, caecal patch and backwash ileitis. Other reasons to separately designate bowel sites are important to note. For one, some cases can be classified as UC or CD only from the course of the disease. Tracking the patients' site-specific histology over time can help establish the diagnosis [60-65] (EL 1a-2b). Moreover, treatment may alter the distribution of inflammation and it may be useful to follow the effects of therapy for each bowel site. This can also lead to accurately establishing if histologic normalization has occurred as a result of therapy [66-73] (EL 1a-2a). Finally, designating different bowel sites can have treatment implications. Local treatment with 5-aminosalicylic acid or steroids is sufficient in most cases of UC that are restricted to the rectum. However, solitary rectal involvement may not be confirmed histologically if the patients' rectal and colonic biopsies are pooled [71-73] (EL 1a).

Table 1 Recommendations that achieved consensus

\begin{tabular}{|c|c|c|c|}
\hline \multirow[t]{2}{*}{ Statement } & \multicolumn{3}{|l|}{ Voting results } \\
\hline & $\begin{array}{l}\text { Votes at last } \\
\text { ballot }(\%)\end{array}$ & $\begin{array}{l}\text { Evidence } \\
\text { level }\end{array}$ & $\begin{array}{l}\text { Recommendation } \\
\text { grade }\end{array}$ \\
\hline $\begin{array}{l}\text { 1. If colonoscopic biopsies are being taken for the diagnosis of chronic idiopathic IBD, the samples } \\
\text { should be sent in separate, designated containers, particularly biopsies of the rectum }\end{array}$ & 95 & $1 \mathrm{a}-2 \mathrm{~b}$ & $\mathrm{~B}$ \\
\hline $\begin{array}{l}\text { 2. } 2 \text { or more tissue samples from separate areas within the same bowel segment should be sent in each } \\
\text { designated container }\end{array}$ & 98 & $1 \mathrm{a}-2 \mathrm{~b}$ & $\mathrm{~B}$ \\
\hline $\begin{array}{l}\text { 3. If Crohn's disease is in question, additional biopsies from the upper gastrointestinal tract should also } \\
\text { be considered }\end{array}$ & 92 & $1 \mathrm{~b}-3 \mathrm{a}$ & $\mathrm{C}$ \\
\hline 4. Assessing the degree of activity should be carried out on the worst affected biopsy & 100 & $1 \mathrm{a}-2 \mathrm{a}$ & $\mathrm{B}$ \\
\hline $\begin{array}{l}\text { 5. The information between pathologist and clinician should include core features that are relevant for } \\
\text { the IBD diagnosis as well as for IBD activity scoring }\end{array}$ & 98 & $1 \mathrm{a}-3 \mathrm{~b}$ & $\mathrm{C}$ \\
\hline $\begin{array}{l}\text { 6. The histological assessment should evaluate the distribution of overall findings, the presence of } \\
\text { chronic injury and the activity of inflammation }\end{array}$ & 100 & $1 \mathrm{a}-3 \mathrm{~b}$ & $\mathrm{C}$ \\
\hline $\begin{array}{l}\text { 7. The scoring system (the IBD-DCA score) developed by the consensus group based on the factors of } \\
\text { distribution (D) of changes, chronic injury (C) and activity of inflammation (A) is a proposal for a } \\
\text { standardized and user-friendly tool for histologic activity assessment }\end{array}$ & 98 & $2 b$ & $\mathrm{~B}$ \\
\hline $\begin{array}{l}\text { 8. The pathology report can include routine text as well as the IBD-DCA score as qualitative and } \\
\text { quantitative information for clinicians }\end{array}$ & 93 & 5 & $\mathrm{D}$ \\
\hline 9. Activity scoring is ideally performed for every container separately & 83 & $1 b-3 b$ & $\mathrm{C}$ \\
\hline 10. The IBD-DCA score is suggested for use in daily routine practice & 95 & 5 & $\mathrm{D}$ \\
\hline
\end{tabular}


Recommendation 2 Two or more tissue samples from separate areas within the same bowel segment should be sent in each designated container (vote: strong consensus (98\%), level of evidence: $1 a-2 b$, recommendation grade: $B$ ).

Evidence and decision Current scoring systems have been applied to biopsy material collected under diverse protocols that include different numbers of tissue samples from different sections of the large bowel. In fact, there are protocols that allow for the bare minimum of rectum-only samples. There is clearly a need to standardize sampling protocols in clinical trials in order to optimize comparisons between treatment outcomes $[20,74]$ (EL 2a-2b). Our recommendation to sample a minimum of 2 biopsies from separate areas within the same bowel segment is therefore intended to standardize and optimize biopsy evaluation. This is supported by Mosli et al. [75]. They concluded that it is imperative to obtain at least $2 \mathrm{mu}-$ cosal biopsy samples for evaluation of UC as the disease changes during the natural disease course and with local and systemic treatment [60, 74-76] (EL 1b-2a). Collecting more than one biopsy also decreases the problem of sample quality and tissue orientation issues. Additionally, as suggested by the ECCO recommendations, biopsies can be properly oriented by use of acetate strips [49, 77]. Further support for the requisite number of biopsy samples is seen in ECCO guidelines, which recommend that a minimum of two biopsies per bowel site be obtained to diagnose CD. For CD, samples should preferably be obtained from both diseased and uninvolved areas [43, 78-86] (EL 1a-2a). If samples are taken only from macroscopically or endoscopically suspicious areas, a pathologist without endoscopic information may not be able to incorporate evidence of discontinuous disease distribution to support an accurate diagnosis of CD. As such, our recommendation advises sampling from separate areas within the same bowel segment and also proper labelling of the containers to ensure that the pathologist receives proper information about the biopsies' origin.

Recommendation 3 If Crohn's disease is in question, additional biopsies from the upper gastrointestinal tract should also be considered (vote: consensus (92\%), level of evidence: $1 b-3 a$, recommendation grade: $C$ ).

Evidence and decision Microscopic inflammation of the upper gastrointestinal (GI) tract is quite common in $\mathrm{CD}$ and comparatively rare in UC [87] (EL 2b). The reported frequency of upper GI tract involvement in CD varies widely, from $6.5 \%$ in a recent analysis of the Swiss IBD Cohort Study Group to $40.7 \%$ in a study of paediatric CD cases, even in the absence of specific upper gastrointestinal symptoms. As such, Castellaneta et al. [88] concluded that upper GI tract endoscopy should be part of the first-line investigation in all new cases suspected of IBD, particularly as the absence of specific upper
GI symptoms does not exclude the presence of upper GI inflammation $[87,89]$ (EL 2b). Patches of acute inflammation of the stomach and duodenum as well as deep acute inflammation of the duodenum raise strong suspicion for $\mathrm{CD}$ in Helicobacter pylori (HP)-negative patients. In fact, the histological pattern of a "focally enhanced" gastritis in HP-negative patients with CD was first described in 1997 by Oberhuber et al. [90] (a participant of the current consensus conference). Overall, they found granulomas and/or a focally enhanced gastritis in $76 \%$ of HP-negative patients with $\mathrm{CD}$ and in $0.8 \%$ of controls. Moreover, there was no correlation between the presence of focally enhanced gastritis and clinical findings [90] (EL 1b). It should be noted, however, that the presence of granulomas is helpful but occurs in only $9-14.6 \%$ of upper GI biopsies [90-92] (EL 1b-3a). In summary, if CD is the diagnosis of clinical concern, the consensus group recommends additional duodenogastroscopy to help consolidate a diagnosis of CD. A minimum of 2 biopsies each from duodenum, antrum and corpus sites should be sent to the pathologist in separate containers $[43,44]$.

Recommendation 4 Assessing the degree of activity should be carried out on the worst affected biopsy (vote: strong consensus (100\%), level of evidence: 1a-2a, recommendation grade: $B)$.

Evidence and decision Assessing the histologic activity of UC is especially important in monitoring treatment follow-up. For clinical trials, scoring is typically performed on the sample exhibiting the highest activity as this may be the most important factor in the further evolution of the disease [75] (EL 1a). It is also important to grade activity based on the most diseased biopsy fragment because it is paramount in establishing whether histologic mucosal healing has truly been achieved. The consensus participants agreed to define histologic mucosal healing as normal mucosa without any pathological changes. This includes the absence of changes seen in quiescent colitis, which encompasses architectural abnormalities as well as increased chronic inflammatory infiltrates. Therefore, grading should be done on the most affected biopsy to indicate if quiescent colitis is present, as quiescent disease is not considered equivalent to the histologic normalization required to meet criteria for histologic mucosal healing. A detailed description of the normal histology of the colon has been published by Levine and Haggitt [93] (EL 2a).

Recommendation 5 The information between pathologist and clinician should include core features that are relevant for the IBD diagnosis as well as for IBD activity scoring (vote: strong consensus (98\%), level of evidence: $1 a-3 b$, recommendation grade: $C$ ).

The following core features (or key elements) refer to details that are essential for the pathologist to be able to establish 
a diagnosis of IBD. They also, in turn, refer to information that the pathologist should communicate to the clinician for the patient's management.

The core features to be communicated to the pathologist by the clinician include:

- Patient's age [92, 94-101] (EL 1a-2b)

In the vast majority, patients with $\mathrm{UC}$ and $\mathrm{CD}$ are usually diagnosed in their 20 s and 30 s, although IBD occurs at any age.

- Type and duration of symptoms $[8,10,12,45]$ (EL 2a-2b)

This information is important given that infectious colitis is one of the main considerations in the differential diagnosis of IBD. The symptoms of infectious colitis can be similar to IBD; however, they usually last for less than 1 month. Therefore, a diagnosis of IBD is more likely with longer duration of symptoms.

- Endoscopic findings: The distribution and type of abnormalities noted on endoscopy should be relayed to the pathologist, along with the key clinical question the pathologist is being asked to address.

- Diagnosis of CD or UC if already known

- Status of current treatment in known IBD patients [22, 24, 25, 45] (EL 1a-2b)

Therapy status is an important piece of information to provide as pathologists can then determine whether treatment has achieved the desired endpoint of histologic mucosal healing. For example, if a pathologist with access to previous biopsy findings and therapy information encounters normal mucosa in areas of known, formerly active IBD, they can establish in their report that histologic normalization has occurred, to indicate that the mucosa has, in fact, normalized due to treatment.

- Specific, designated sites from which biopsies have been taken $[45,55]$.

Biopsies from different bowel segments should be submitted in such a way that their site of origin can be determined reliably. This issue is discussed further with statement 2 , mentioned previously.

Core histologic features to be communicated to the clinicians include:

- Diagnosis of IBD or others

- Distinction between UC and CD [16,44-51, 102] (EL 1b2a)

- The term "indeterminate colitis" should be avoided as it causes confusion and can be used incorrectly. Rather, it is recommended that a pathologist state that IBD is present and the features favour one disease type over the other, but that definitive classification may depend on the clinical course.

- Exclusion of dysplasia or malignancy $[62,64]$
- Information regarding the adequacy and/or limitations of the submitted material, i.e. a statement about the sufficient number of biopsies (see recommendation 2)

- In case of insufficiently labelled containers, feedback to the clinicians that the origin of the biopsies cannot reliably be assessed, limiting assessment for IBD diagnosis.

- Potential limitations due to biopsy orientation or artefacts

Assessment of certain features such as distribution of changes or presence and extent of a basal plasmacytosis is limited if the material is insufficient and poorly oriented. Use of acetate strips can be helpful for proper biopsy orientation $[45,103]$.

Recommendation 6 The histological assessment should evaluate the distribution of overall findings, presence of chronic injury and activity of inflammation (vote: strong consensus (100\%), level of evidence: $1 a-3 b$, recommendation grade: $C$ ).

\section{Evidence and decision}

\section{Distribution}

Evaluating the distribution of microscopic changes can serve as a quantitative marker for assessing overall deviations from normal mucosa. It particularly pertains to the pattern and amount of tissue involved by chronic injury and active inflammation. The abnormalities can vary within a single biopsy, within different biopsies from the same site as well as among different anatomical sites. This heterogeneity of disease involvement is typical of $\mathrm{CD}$ but can also be seen in UC especially after treatment $[60$, 66-73, 75, 76, 78-91, 93] (EL 1b-2b).

Terms that are sometimes used by pathologists to assess disease involvement, such as "diffuse", "patchy" or "focal", are ill-defined and can be subjective. It is preferable to use alternative terms such as "continous between sites", "discontinous between sites" or "segmental" (anatomically non-continuous) [14] (EL 2a). Assessing the distribution of changes is helpful for distinguishing $\mathrm{UC}$ from CD. Moreover, in the course of known IBD, reporting the distribution of changes can provide important information regarding response to treatment in a quantitative fashion $[4,60-62$, 74, 104, 105] (EL 1a-2a).

\section{Chronicity}

As most adult IBD patients present after at least 6 weeks of symptoms, features of chronic injury are often already discernible on their GI biopsies at initial diagnosis $[10,106]$ (EL 2a-2b). Features of chronic injury include architectural distortion and chronic inflammatory infiltrates in the lamina propria [10] (EL 2a). Basal plasmacytosis is probably the 
earliest sign of chronic injury and has proven to be the strongest and highest reliable predictor of IBD. This feature was demonstrated to achieve almost perfect intrarater as well as substantial interrater reproducibility rates and can have significant prognostic implications. Moreover, on rectal biopsy specimens, basal plasmacytosis has been shown to be one of several independent predictors of earlier relapse in UC patients $[9,10,21,29,107,108]$ (EL 2a-3b). Another feature of chronic injury, architectural distortion, is typically not seen before 15 days of symptoms. However, it is present in more than $75 \%$ of patients after 4 months $[10,16]$ (EL 2a). This feature is also associated with almost perfect intraobserver and substantial interobserver agreement rates [107] (EL 2b). Some of the existing scoring indices for evaluating UC disease activity do not include architectural distortion, as this feature was not considered to be a marker for disease activity and was also considered unlikely to be responsive to therapy. This, however, proved to be false, as complete histologic mucosal normalization is now an attainable treatment goal $[10$, 37, 104, 109] (EL 1b-2b). Crypt architectural distortion may, in fact, be the only feature able to distinguish between remission and true histological normalization, given the feature's lengthier persistence. This is in contrast to basal plasmacytosis, which may diminish earlier with longstanding or treated disease $[10,45,110]$ (EL 2a-3b). Additional features of chronic injury are Paneth cell metaplasia (especially distal the splenic flexure), pseudopolyps, hypertrophy of the muscularis mucosae and submucosal fibrosis [105] (EL 2a).

The role of increased eosinophils in IBD is unclear. Eosinophils are part of the normal mucosa, and their number is highly variable [93] (EL 2a). Due to a lack of reproducibility and only moderate interobserver agreement, the ECCO recommended that eosinophils alone should not be used as a marker of histological activity in UC $[16,41,106]$ (EL 2a).

\section{Activity}

Disease activity as measured histologically is ascertained by the presence of neutrophilic granulocytes and their damage to the epithelium. Cryptitis, crypt abscess formation as well as erosions and ulcerations represent the spectrum of active inflammation in order of increasing severity $[11,12,14,111$, 112] (EL 1a-2b). Whilst some question the significance and reproducibility of histologic activity, the presence of acute inflammatory infiltrates is actually associated with a twofold to threefold increased risk of relapse within 12 months of follow-up and an increased use of systemic corticosteroids, colectomy and hospitalization within 3 years of follow-up $[20,113]$ (EL 2b). Moreover, assessing for acute inflammatory infiltrates such as neutrophils in the lamina propria, intraepithelial neutrophils, erosions or ulceration attained good reproducibility in existing scoring systems [107, 109, 114-116] (EL 2b).
Recommendation 7 The scoring system (the IBD-DCA score) developed by the consensus group based on the factors of distribution (D) of changes, chronic injury (C) and activity of inflammation (A) is a proposal for a standardized and user-friendly tool for histologic activity assessment (vote: strong consensus (98\%), level of evidence: $2 b$, recommendation grade: $B$ ).

The proposed "Inflammatory Bowel Disease Distribution, Chronicity, Activity" (IBD-DCA) score comprises the three parameters - distribution (D), chronicity (C) and activity (A) - and is determined in that order. The individual items constituting the parameters $\mathrm{C}$ and $\mathrm{A}$ were selected on the basis of previous research, with particular selection of features that have achieved good reliability in existing scoring systems in order to be eligible candidates for the index development (supplemental Table 2).

\section{Distribution parameter (D)}

Parameter D is used to estimate the overall extent of mucosal abnormalities, regardless of whether they represent architectural distortion, chronic inflammation or active inflammatory infiltrates. D0 is assigned for completely normal mucosa without any pathological changes. D1 is assigned if changes are present in less than $50 \%$ of all tissue fragments. D2 is assigned for changes that involve $50 \%$ or more of the tissue.

\section{Chronicity parameter (C)}

Parameter C encompasses crypt architectural distortion as well as elevated lymphoplasmacytic cell count in the lamina propria (including basal plasmacytosis). $\mathrm{C} 0$ refers to mucosa without chronic changes, i.e. absence of elevated lymphoplasmacytic cell count and absence of crypt architectural distortion. $\mathrm{C} 1$ refers to crypt distortion and/or mildly elevated lamina propria lymphoplasmacytosis (mildly more lymphocytes and plasma cells than in the normal mucosa). C2 necessitates a marked elevated lymphoplasmacytic cell count in the lamina propria regardless of the additional presence of crypt distortion. A marked basal lymphoplasmacytosis is also assessed as $\mathrm{C} 2$.

\section{Activity parameter (A)}

Parameter A refers to the presence and degree of tissue involvement by neutrophilic granulocytes. A0 is assessed in the absence of neutrophilic granulocytes. The number of neutrophils that are allowed in a normal lamina propria ranges in the literature between 0 and 1 [17, 93] (EL 2a). Neutrophils are not normally present in the surface or crypt epithelium [93] (EL 2a). Therefore, A1 is assessed for an increase of two or more neutrophils in the lamina propria in one high-power field (HPF) or one or more neutrophils in the epithelium (as in 
cryptitis or neutrophils in the surface epithelium). To reach the intestinal lumen, neutrophils must first exit the blood vessels, migrate across the lamina propria and finally cross the epithelial barrier in that order [77] (EL 2a). Therefore, A2 is assigned in the presence of crypt abscesses, erosion or ulceration as they have breaks of the mucosal barrier in common.

A validation of the IBD-DCA score was performed after the meeting (Lang-Schwarz et al., submitted).

Figure 1 shows the proposed algorithmic assessment of the IBD-DCA score.

Recommendation 8 The pathology report can include routine text as well as the IBD-DCA score as qualitative and quantitative information for clinicians (vote: consensus (93\%), level of evidence: 5 , recommendation grade: $D$ ).

Evidence and decision The IBD-DCA score is not intended to replace the pathologist's individual text reports, but it can act as an additional tool to summarize histologic activity qualitatively and quantitatively. Clinicians and pathologists in their professional partnerships may already have established means of relaying important patient information with one another through the language of their individual reports. The additional proposed benefit in reporting the IBD-DCA score, however, is its facilitation in disease monitoring, given that each parameter can be quickly and easily compared to previous findings during a patient's follow-up.

Example reports:

- Ulcerative proctitis, marked activity; IBD-DCA score: D2, C2, A2

- Ulcerative proctitis, remission; IBD-DCA score: D1, C1, A0
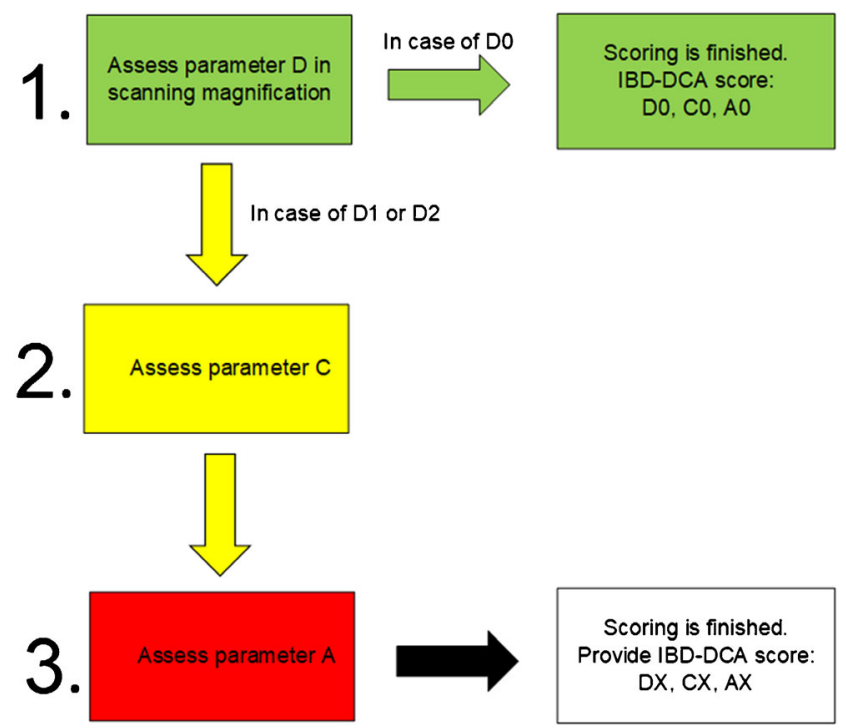

Fig. 1 Proposed stepwise algorithmic assessment of the ID-DCA score
- Ulcerative proctitis, histologic mucosal healing; IBDDCA-score: D0, C0, A0

Recommendation 9 Activity scoring is ideally performed for every container separately (vote: consensus (83\%), level of evidence: $1 b-3 b$, recommendation grade: $C)$.

Evidence and decision Scoring each site separately may help distinguish CD from UC diagnostically. A discontinuous and focal pattern of disease involvement is typical for CD, whereas UC classically shows diffuse mucosal inflammation $[4,108]$ (EL 2a-3b). There is also a known gradient of disease severity that increases from proximal to distal colon in UC, versus the opposite pattern in CD in many cases, which is helpful in distinguishing both entities [4] (EL 2a). Performing the above scoring index for each gastrointestinal biopsy site can, in fact, highlight these distinguishing attributes and support the diagnosis. Secondly, as treatment is able to alter the usual distribution of IBD and therapy response can vary between bowel segments, the participants agreed that activity scoring according to the IBD-DCA score should be performed for each designated site [61, 66-70] (EL 1b-2b). Nevertheless, effective scoring obviously depends on the endoscopist's sampling, as detailed in statements above. Moreover, scoring and reporting each site if diagnosis and result are exactly the same for every container may not be necessary and a representative single score encompassing those parts could be done in such situations.

- Example: ulcerative pancolitis, markedly active in sigmoid (D2C2A2), mildly active in all other sites (D2C1A1)

Recommendation 10 The IBD-DCA score is appropriate for use in daily routine practice (vote: strong consensus (95\%), level of evidence: 5 , recommendation grade: $D$ ).

Evidence and decision The design of the IBD-DCA score is intended to be simple and user-friendly, with the purpose of emulating the manner in which pathologists intuitively assess samples from low to high power magnification in daily practice. Therefore, it is well suited to be applied to biopsy specimen in daily routine diagnostics as well as clinical trials. It can be applied to biopsies from UC as well as CD patients. However, its significance in CD and also its applicability to the upper GI tract have to be further investigated. The validation of the index has proven its reproducibility, feasibility, construct validity as well as its ability to provide reliable information about response to treatment (Lang-Schwarz et al., submitted). 


\section{Conclusion and further perspectives}

Assessing the presence and degree of disease activity in IBD patients is important for developing optimal therapeutic strategies and timing of follow-up [117-119]. As UC activity scoring warrants both endoscopic and histologic evaluations, there is a need for standardized biopsy procedures and a simple, validated scoring system that can be used globally. Moreover, such a scoring index should be able to discriminate between quiescence and histologic mucosal healing as histologic mucosal healing is emerging as the desired therapeutic goal. Histological mucosal healing is not well defined to date. In their "Histology Position 3.4", the ECCO refers to "return to normal" as the strictest definition of histological remission [41]. A new key feature of histologic mucosal healing might therefore lie in identifying the absence of crypt architectural distortion, thus distinguishing between quiescent UC (which has architectural distortion) and true histological normalization (which looks like normal colon) [10, 74]. Two recent studies by Christensen et al. [37, 120] suggest that histologic normalization differs clinically from histologic quiescence by being independently associated with increased relapse-free survival in $\mathrm{UC}$ and $\mathrm{CD}$, reduced medication escalation and reduced corticosteroid use $[37,120]$. To date, many different scoring systems exist for assessing histologic activity in UC and $\mathrm{CD}$. The Cochrane Collaboration recently reviewed 14 different histologic scoring systems for CD as well as 30 indices for UC by highlighting their different advantages and disadvantages [39, 40]. Some of the systems are simple, whilst others are very detailed. For UC, the Nancy Histological Index (NHI) and the Robarts Histopathology Index (RHI) have undergone the most validation, even if the feasibility of these indices has not been assessed [109, 114]. Therefore, the ECCO recommended recently the use of both indices for randomized control trials in ulcerative colitis and the use of the NHI for observational studies or in clinical practice [41].

However, neither the NHI nor the RHI includes architectural features, which means that they cannot distinguish between histologic quiescent disease (in which crypt architectural distortion is often the only visible feature) and histological complete normal mucosa. As for $\mathrm{CD}$, the existing indices have yet to be validated and none of them is recommended for use to date.

In order to address such issues, the International Consensus Conference on IBD Activity Scoring assented on the above statements with the goal of maximizing diagnostic information from biopsies as relevant in the modern era of IBD therapy and of optimizing communication between clinicians and pathologists to enhance patient care. The statements are in line with published recommendations from internationally recognized organizations such as ECCO, the BSG, the ACG, the ASGE and the WGO, and they are intended to consolidate the factors most relevant to patient care and raise awareness regarding the need for these clinically relevant matters to be applied more consistently in daily practice. The group agreed on ten statements which received a high level of agreement. Since the participants represented centres from different countries worldwide, this agreement suggests notable international recognition on the topics considered.

Additionally, we present the IBD-DCA score, a proposal for an international, consensus-approved histologic activity scoring index, intended for use in routine practice and clinical trials. The scoring index is able to distinguish between quiescence and true histological mucosal healing. Furthermore, it includes a statement on the quantity as well as the quality of inflammatory changes. Apart from normal, grading of chronicity and activity is reported in a two-tiered fashion in the IBD-DCA score, distinguishing only between low- and highlevel inflammatory changes. The terms "low-" and "highgrade" are, however, intentionally omitted to avoid confusion as these terms are traditionally used for dysplasia. The simplicity of the index makes it likely to be used by pathologists and also to be accepted by the clinicians. It should be applicable for UC and may also be applicable for CD in both the upper and lower GI tract. Noteworthy that the index may be used for patients with proven IBD during follow-up to assess changes over time. However, the main limitation of this study is the fact that the proposed index has not been tested prospectively so far. Validation by an independent research group is clearly necessary. Also, its use in CD needs further validation studies, due to the potential limitations of histologic activity scoring in the discontinuous disease involvement inherent in the nature of $\mathrm{CD}$.

Supplementary Information The online version contains supplementary material available at https://doi.org/10.1007/s00428-020-02982-7.

Authors' contributions Organization of the meeting and steering committee: Michael Vieth, Arndt Hartmann and Markus F. Neurath. Writing and editing: Corinna Lang-Schwarz and Maria Westerhoff.

This paper is a joint expert consensus activity. Hence, all authors participated sufficiently, intellectually and practically in this work. All authors contributed to the critical review and revision of each draft of the manuscript and approved the final version for submission.

Funding Open Access funding enabled and organized by Projekt DEAL.

Data availability Data and material (as far as not published) are available on demand via e-mail at vieth.lk-pathol@uni-bayreuth.de.

\section{Compliance with ethical standards}

Competing interests Michael Vieth reports lecture fees from Falk, Shire, Lilly, Malesci, Pentax, Olympus and AstraZeneca.

Raja Atreya has served as a speaker, or consultant, or received research grants from AbbVie, Biogen, Boehringer Ingelheim, Celgene, Celltrion, Dr. Falk Pharma, Ferring, InDex Pharmaceuticals, JanssenCilag, MSD Sharp \& Dome, Pfizer, Roche Pharma, Samsung Bioepis and Takeda. 
Gregory Y. Lauwers is a consultant for Alimentiv.

Vincenco Villanacci, Corinna Lang-Schwarz, Kieran Sheahan, Alessandro Lugli, Carlos A. Rubio, Maria Westerhoff, Nikolaus Gassler, Kateřina Kamarádová, Jean-François Fléjou, Timo Rath, Fulvia Ferrazzi, Miriam Angeloni, Abbas Agaimy, Arndt Hartmann, Anja A. Kühl, Heike I. Grabsch, Iris Nagtegaal, Markus F. Neurath, Georg Oberhuber, Christoph Becker, Robert Riddell, Silvio Danese and Herbert Tilg declare that they have no competing interests.

Ethical approval Ethical approval was obtained from the ethics committee of Friedrich-Alexander University, Erlangen-Nuremberg, Germany, for validation of the IBD-DCA score (study number: $175 \_20 \mathrm{Bc}$ ).

\section{Consent to participate All authors consented to participate.}

Consent for publication All authors proved the final version for submission.

\section{Code availability None}

Open Access This article is licensed under a Creative Commons Attribution 4.0 International License, which permits use, sharing, adaptation, distribution and reproduction in any medium or format, as long as you give appropriate credit to the original author(s) and the source, provide a link to the Creative Commons licence, and indicate if changes were made. The images or other third party material in this article are included in the article's Creative Commons licence, unless indicated otherwise in a credit line to the material. If material is not included in the article's Creative Commons licence and your intended use is not permitted by statutory regulation or exceeds the permitted use, you will need to obtain permission directly from the copyright holder. To view a copy of this licence, visit http://creativecommons.org/licenses/by/4.0/.

\section{References}

1. GBD 2017 Inflammatory Bowel Disease Collaborators (2020) The global, regional, and national burden of inflammatory bowel disease in 195 countries and territories, 1990-2017: a systematic analysis for the Global Burden of Disease Study 2017. Lancet Gastroenterol Hepatol 5:17-30. https://doi.org/10.1016/S24681253(19)30333-4

2. Kucharzik A, Dignass AU, Atreya R et al (2018) Updated S3Guideline colitis ulcerosa. German Society for Digestive and Metabolic Diseases (DGVS) - AWMF Registry 021/009. Z Gastroenterol 56:1087-1169

3. Allison MC, Hamilton-Dutoit SJ, Dhillon AP et al (1987) The value of rectal biopsy in distinguishing self-limited colitis from early inflammatory bowel disease. Q J Med 65:985-995

4. Bentley E, Jenkins D, Campbell F, Warren B (2002) How could pathologists improve the initial diagnosis of colitis? Evidence from an international workshop. J Clin Pathol 55:955-960. https://doi.org/10.1136/jcp.55.12.955

5. Dejaco C, Oesterreicher C, Angelberger S, Püspök A, Birner P, Poetzi R, Gangl A, Oberhuber G (2003) Diagnosing colitis: a prospective study on essential parameters for reaching a diagnosis. Endoscopy 35:1004-1008. https://doi.org/10.1055/s-2003-44593

6. Dube AK, Cross SS, Lobo AJ (1998) Audit of the histopathological diagnosis of non-neoplastic colorectal biopsies: achievable standards for the diagnosis of inflammatory bowel disease. J Clin Pathol 51:378-381. https://doi.org/10.1136/jcp.51.5.378

7. Dundas SA, Dutton J, Skipworth P (1997) Reliability of rectal biopsy in distinguishing between chronic inflammatory bowel disease and acute self-limiting colitis. Histopathology 31:60-66. https://doi.org/10.1046/j.1365-2559.1997.5810818.x

8. Jenkins D, Balsitis M, Gallivan S, Dixon MF, Gilmour HM, Shepherd NA, Theodossi A, Williams GT (1997) Guidelines for the initial biopsy diagnosis of suspected chronic idiopathic inflammatory bowel disease. The British Society of Gastroenterology Initiative. J Clin Pathol 50:93-105

9. Nostrant TT, Kumar NB, Appelman HD (1987) Histopathology differentiates acute self-limited colitis from ulcerative colitis. Gastroenterology 92:318-328. https://doi.org/10.1016/00165085(87)90124-7

10. Schumacher G, Kollberg B, Sandstedt B (1994) A prospective study of first attacks of inflammatory bowel disease and infectious colitis. Histologic course during the 1st year after presentation. Scand J Gastroenterol 29:318-332. https://doi.org/10.3109/ 00365529309098313

11. Seldenrijk CA, Morson BC, Meuwissen SG, Schipper NW, Lindeman J, Meijer CJ (1991) Histopathological evaluation of colonic mucosal biopsy specimens in chronic inflammatory bowel disease: diagnostic implications. Gut 32:1514-1520. https://doi. org/10.1136/gut.32.12.1514

12. Surawicz CM, Belic L (1984) Rectal biopsy helps to distinguish acute self-limited colitis from idiopathic inflammatory bowel disease. Gastroenterology 86:104-113

13. Tanaka M, Masuda T, Yao T, Saito H, Kusumi T, Nagura H, Kudo H (2001) Observer variation of diagnoses based on simple biopsy criteria differentiating among Crohn s disease, ulcerative colitis, and other forms of colitis. J Gastroenterol Hepatol 16: 1368-1372. https://doi.org/10.1046/j.1440-1746.2001.02638.x

14. Tanaka M, Riddell RH, Saito H, Soma Y, Hidaka H, Kudo H (1999) Morphologic criteria applicable to biopsy specimens for effective distinction of inflammatory bowel disease from other forms of colitis and of Crohn s disease from ulcerative colitis. Scand J Gastroenterol 34:55-67. https://doi.org/10.1080/ 00365529950172844

15. Tanaka M, Saito H, Fukuda S, Sasaki Y, Munakata A, Kudo H (2000) Simple mucosal biopsy criteria differentiating among Crohn disease, ulcerative colitis, and other forms of colitis: measurement of validity. Scand J Gastroenterol 35:281-286. https:// doi.org/10.1080/003655200750024155

16. Theodossi A, Spiegelhalter DJ, Jass J, Firth J, Dixon M, Leader M, Levison DA, Lindley R, Filipe I, Price A (1994) Observer variation and discriminatory value of biopsy features in inflammatory bowel disease. Gut 35:961-968. https://doi.org/10.1136/gut.35.7. 961

17. Langner C, Magro F, Driessen A, Ensari A, Mantzaris GJ, Villanacci V, Becheanu G, Borralho Nunes P, Cathomas G, Fries W, Jouret-Mourin A, Mescoli C, de Petris G, Rubio CA, Shepherd NA, Vieth M, Eliakim R, Geboes K (2014) The histopathological approach to inflammatory bowel disease: a practice guide. Virchows Arch 464(5):511-527. https://doi.org/10.1007/ s00428-014-1543-4

18. Lichtenstein GR, Loftus EV, Isaacs KL, Regueiro MD, Gerson LB, Sands BE (2018) ACG clinical guideline: management of Crohn's disease in adults. Am J Gastroenterol 113:481-517. https://doi.org/10.1038/ajg.2018.27

19. Rubin DT, Ananthakrishnan AN, Siegel CA, Sauer BG, Long MD (2019) ACG clinical guideline: ulcerative colitis in adults. Am J Gastroenterol 114:384-413. https://doi.org/10.14309/ajg. 0000000000000152

20. Riley SA, Mani V, Goodman MJ, Dutt S, Herd ME (1991) Microscopic activity in ulcerative colitis: what does it mean? Gut 32:174-178. https://doi.org/10.1136/gut.32.2.174

21. Bitton A, Peppercorn MA, Antonioli DA, Niles JL, Shah S, Bousvaros A, Ransil B, Wild G, Cohen A, Deb Edwardes MD, Stevens AC (2001) Clinical, biological, and histologic parameters 
as predictors of relapse in ulcerative colitis. Gastroenterology 120 : 13-20. https://doi.org/10.1053/gast.2001.20912

22. Neurath MF, Travis SP (2012) Mucosal healing in inflammatory bowel diseases: a systematic review. Gut 61:1619-1635. https:// doi.org/10.1136/gutjnl-2012-302830

23. Truelove SC, Richards WC (1956) Biopsy studies in ulcerative colitis. Br Med J 1:1315-1318. https://doi.org/10.1136/bmj.1. 4979.1315

24. Frøslie KF, Jahnsen J, Moum BA, Vatn MH (2007) Mucosal healing in inflammatory bowel disease: results from a Norwegian population-based cohort. Gastroenterology 133:412422. https://doi.org/10.1053/j.gastro.2007.05.051

25. Colombel JF, Rutgeerts P, Reinisch W, Esser D, Wang Y, Lang Y, Marano CW, Strauss R, Oddens BJ, Feagan BG, Hanauer SB, Lichtenstein GR, Present D, Sands BE, Sandborn WJ (2011) Early mucosal healing with infliximab is associated with improved long-term clinical outcomes in ulcerative colitis. Gastroenterology 141:1194-1201. https://doi.org/10.1053/j. gastro.2011.06.054

26. Sandborn WJ, Rutgeerts P, Feagan BG, Reinisch W, Olson A, Johanns J, Lu J, Horgan K, Rachmilewitz D, Hanauer SB, Lichtenstein GR, de Villiers WJS, Present D, Sands BE, Colombel JF (2009) Colectomy rate comparison after treatment of ulcerative colitis with placebo or infliximab. Gastroenterology 137:1250-1260. https://doi.org/10.1053/j.gastro.2009.06.061

27. Feagan BG, Reinisch W, Rutgeerts P, Sandborn WJ, Yan S, Eisenberg D, Bala M, Johanns J, Olson A, Hanauer SB (2007) The effects of infliximab therapy on health-related quality of life in ulcerative colitis patients. Am J Gastroenterol 102:794-802. https://doi.org/10.1111/j.1572-0241.2007.01094.x

28. Peyrin-Biroulet L, Sandborn W, Sands BE, Reinisch W, Bemelman W, Bryant RV, D Haens G, Dotan I, Dubinsky M, Feagan B, Fiorino G, Gearry R, Krishnareddy S, Lakatos PL, Loftus EV Jr, Marteau P, Munkholm P, Murdoch TB, Ordás I, Panaccione R, Riddell RH, Ruel J, Rubin DT, Samaan M, Siegel CA, Silverberg MS, Stoker J, Schreiber S, Travis S, van Assche G, Danese S, Panes J, Bouguen G, O Donnell S, Pariente B, Winer S, Hanauer S, Colombel JF (2015) Selecting Therapeutic Targets in Inflammatory Bowel Disease (STRIDE): determining therapeutic goals for treat-to-target. Am J Gastroenterol 110: 1324-1328. https://doi.org/10.1038/ajg.2015.233

29. Bessissow T, Lemmens B, Ferrante M, Bisschops R, van Steen K, Geboes K, van Assche G, Vermeire S, Rutgeerts P, de Hertogh G (2012) Prognostic value of serologic and histologic markers on clinical relapse in ulcerative colitis patients with mucosal healing. Am J Gastroenterol 107:1684-1692. https://doi.org/10.1038/ajg. 2012.301

30. Park S, Abdi T, Gentry M, Laine L (2016) Histological disease activity as a predictor of clinical relapse among patients with ulcerative colitis: systematic review and meta-analysis. Am J Gastroenterol 111:1692-1701. https://doi.org/10.1038/ajg.2016. 418

31. Rubin DT, Huo D, Kinnucan JA, Sedrak MS, McCullom NE, Bunnag AP, Raun-Royer EP, Cohen RD, Hanauer SB, Hart J, Turner JR (2013) Inflammation is an independent risk factor for colonic neoplasia in patients with ulcerative colitis: a case-control study. Clin Gastroenterol Hepatol 11:1601-1608. https://doi.org/ 10.1016/j.cgh.2013.06.023

32. Gupta RB, Harpaz N, Itzkowitz S, Hossain S, Matula S, Kornbluth A, Bodian C, Ullman T (2007) Histologic inflammation is a risk factor for progression to colorectal neoplasia in ulcerative colitis: a cohort study. Gastroenterology 133:1099-1105. https://doi.org/ 10.1053/j.gastro.2007.08.001

33. Hefti MM, Chessin DB, Harpaz NH, Steinhagen RM, Ullman TA (2009) Severity of inflammation as a predictor of colectomy in patients with chronic ulcerative colitis. Dis Colon Rectum 52: 193-197. https://doi.org/10.1007/DCR.0b013e31819ad456

34. Bryant RV, Burger DC, Delo J, Walsh AJ, Thomas S, von Herbay A, Buchel OC, White L, Brain O, Keshav S, Warren BF, Travis SPL (2016) Beyond endoscopic mucosal healing in UC: histological remission better predicts corticosteroid use and hospitalisation over 6 years of follow-up. Gut 65(3):408-414. https://doi.org/10. 1136/gutjnl-2015-309598

35. Peyrin-Biroulet L, Bressenot A, Kampman W (2014) Histologic remission: the ultimate therapeutic goal in ulcerative colitis? Clin Gastroenterol Hepatol 12:929-934. https://doi.org/10.1016/j.cgh. 2013.07.022

36. Feagins LA, Melton SD, Iqbal R, Dunbar KB, Spechler SJ (2013) Clinical implications of histologic abnormalities in colonic biopsy specimens from patients with ulcerative colitis in clinical remission. Inflamm Bowel Dis 18:1477-1482. https://doi.org/10.1097/ MIB.0b013e318281f4ae

37. Christensen B, Hanauer SB, Erlich J, Kassim O, Gibson PR, Turner JR, Hart J, Rubin DT (2017) Histologic normalization occurs in ulcerative colitis and is associated with improved clinical outcomes. Clin Gastroenterol Hepatol 15:1557-1564. https://doi. org/10.1016/j.cgh.2017.02.016

38. Food and Drug Administration. Ulcerative colitis: clinical trial endpoints guidance for industry. Draft Guidance. Silver Spring, MD: FDA; p. 19. Report No.: 15028dft.doc 07/27/16 UCM515143. Available from: https://www.fda.gov/regulatoryinformation/search-fda-guidance-documents/ulcerative-colitisclinical-trial-endpoints-guidance-industry.

39. Novak G, Parker CE, Pai RK, MacDonald JK, Feagan BG, Sandborn WJ, D'Haens G, Jairath V, Khanna R (2017) Histologic scoring indices for evaluation of disease activity in Crohn's disease. Cochrane Database Syst Rev 7:CD012351. https://doi.org/10.1002/14651858.CD012351.pub2

40. Mosli MH, Parker CE, Nelson SA et al (2017) Histologic scoring indices for evaluation of disease activity in ulcerative colitis. Cochrane Database Syst Rev 5:CD011256. https://doi.org/10. 1002/14651858.CD011256.pub2

41. Magro F, Doherty G, Peyrin-Biroulet L et al (2020) ECCO position paper: harmonization of the approach to ulcerative colitis histopathology. J Crohns Colitis 14(11):1503-1511. https://doi. org/10.1093/ecco-jcc/jjaa1 10 [Published Online ahead of print]

42. Likert R (1932) A technique for the measurement of attitudes. In: Archives of Psychology 22(140):55

43. Gomollón F, Dignass A, Annese V, Tilg H, van Assche G, Lindsay JO, Peyrin-Biroulet L, Cullen GJ, Daperno M, Kucharzik T, Rieder F, Almer S, Armuzzi A, Harbord M, Langhorst J, Sans M, Chowers Y, Fiorino G, Juillerat P, Mantzaris GJ, Rizzello F, Vavricka S, Gionchetti P, on behalf of ECCO (2017) 3rd European Evidence-based Consensus on the Diagnosis and Management of Crohn's Disease 2016: part 1: diagnosis and medical management. J Crohns Colitis 11:3-25. https://doi.org/10.1093/ecco-jcc/jjw168

44. Feakins RM (2013) Inflammatory bowel disease biopsies: updated British Society of Gastroenterology reporting guidelines. J Clin Pathol 66:1-22. https://doi.org/10.1136/jclinpath-2013-201885

45. Stange EF, Travis SPL, Vermeire S, Reinisch W, Geboes K, Barakauskiene A, Feakins R, Fléjou JF, Herfarth H, Hommes DW, Kupcinskas L, Lakatos PL, Mantzaris GJ, Schreiber S, Villanacci V, Warren BF, European Crohn's and Colitis Organisation (ECCO) (2008) European evidence-based consensus on the diagnosis and management of ulcerative colitis: definitions and diagnosis. J Crohns Colitis 2:1-23. https://doi.org/10.1016/j. crohns.2007.11.001

46. Stange EF, Travis SPL, Vermeire S, Beglinger C, Kupcinkas L, Geboes K, Barakauskiene A, Villanacci V, von Herbay A, Warren BF, Gasche C, Tilg H, Schreiber SW, Schölmerich J, Reinisch W, 
European Crohn's and Colitis Organisation (2006) European evidence based consensus on the diagnosis and management of Crohn's disease: definitions and diagnosis. Gut 55(suppl 1):115. https://doi.org/10.1136/gut.2005.081950a

47. Bernstein C, Eliakim A, Fedail S, Fried M, Gearry R, Goh KL, Hamid S, Khan AG, Khalif I, Ng SC, Ouyang Q, Rey JF, Sood A, Steinwurz F, Watermeyer G, LeMair A, Review Team (2015) World Gastroenterology Organisation Global Guidelines Inflammatory Bowel Disease: update August 2015. J Clin Gastroenterol 50(10):803-818. https://doi.org/10.1097/MCG. 0000000000000660

48. Magro F, Langner C, Driessen A, Ensari A, Geboes K, Mantzaris GJ, Villanacci V, Becheanu G, Borralho Nunes P, Cathomas G, Fries W, Jouret-Mourin A, Mescoli C, de Petris G, Rubio CA, Shepherd NA, Vieth M, Eliakim R, European Society of Pathology (ESP), European Crohn's and Colitis Organisation (ECCO) (2013) European consensus on the histopathology of inflammatory bowel disease. J Crohns Colitis 7:827-851. https:// doi.org/10.1016/j.crohns.2013.06.001

49. Dignass A, Eliakim R, Magro F, Maaser C, Chowers Y, Geboes K, Mantzaris G, Reinisch W, Colombel JF, Vermeire S, Travis S, Lindsay JO, van Assche G (2012) Second European evidencebased consensus on the diagnosis and management of ulcerative colitis. Part 1: definitions and diagnosis. J Crohns Colitis 6(10): 965-990. https://doi.org/10.1016/j.crohns.2012.09.003

50. Lamb CA, Kennedy NA, Raine T, Hendy PA, Smith PJ, Limdi JK, Hayee B'H, Lomer MCE, Parkes GC, Selinger C, Barrett KJ, Davies RJ, Bennett C, Gittens S, Dunlop MG, Faiz O, Fraser A, Garrick V, Johnston PD, Parkes M, Sanderson J, Terry H, IBD guidelines eDelphi consensus group, Gaya DR, Iqbal TH, Taylor SA, Smith M, Brookes M, Hansen R, Hawthorne AB (2019) British Society of Gastroenterology consensus guidelines on the management of inflammatory bowel disease in adults. Gut 68(Suppl 3):s1-s106. https://doi.org/10.1136/gutjnl-2019-318484

51. Sharaf RN, Shergill AK, Odze RD et al (2013) Endoscopic mucosal tissue sampling. Gastrointest Endosc 78(2):216-224. https:// doi.org/10.1016/j.gie.2013.04.167

52. OCEBM Levels of Evidence Working Group. The Oxford 2011 Levels of Evidence. Oxford Centre for Evidence-Based Medicine. http://www.cebm.net/index.aspx?o=565.

53. Annese V, Daperno M, Rutter MD, Amiot A, Bossuyt P, East J, Ferrante M, Götz M, Katsanos KH, Kießlich R, Ordás I, Repici A, Rosa B, Sebastian S, Kucharzik T, Eliakim R, European Crohn's and Colitis Organisation (2013) European evidence based consensus for endoscopy in inflammatory bowel disease. J Crohns Colitis 7:982-1018. https://doi.org/10.1016/j.crohns.2013.09.016

54. Carter MJ, Lobo AJ, Travis SP (2004) IBD Section, British Society of Gastroenterology. Guidelines for the management of inflammatory bowel disease in adults. Gut 53(Suppl 5):1-16. https://doi.org/10.1136/gut.2004.043372

55. Feakins RM, Campbell F, Mears L et al (2009) Tissue pathways for gastrointestinal and hepatopancreatobiliary pathology. Royal College of Pathologists, London

56. Carbonnel F, Lavergne A, Lemann M et al (1994) Colonoscopy of acute colitis. A safe and reliable tool for assessment of severity. Dig Dis Sci 39:1550-1557. https://doi.org/10.1007/BF02088063

57. Washington K, Greenson JK, Montgomery E, Shyr Y, Crissinger KD, Polk DB, Barnard J, Lauwers GY (2002) Histopathology of ulcerative colitis in initial rectal biopsy in children. Am J Surg Pathol 26:1441-1449. https://doi.org/10.1097/00000478200211000-00006

58. Coremans G, Rutgeerts P, Geboes K, van den Oord J, Ponette E, Vantrappen G (1984) The value of ileoscopy with biopsy in the diagnosis of intestinal Crohn's disease. Gastrointest Endosc 30: 167-172. https://doi.org/10.1016/s0016-5107(84)72358-3
59. Alemayehu G, Jarnerot G (1991) Colonoscopy during an attack of severe ulcerative colitis is a safe procedure and of great value in clinical decision making. Am J Gastroenterol 86:187-190

60. Kleer CG, Appelman HD (1998) Ulcerative colitis: patterns of involvement in colorectal biopsies and changes with time. Am J Surg Pathol 22:983-989. https://doi.org/10.1097/00000478199808000-00008

61. Mutinga ML, Odze RD, Wang HH, Hornick JL, Farraye FA (2004) The clinical significance of right-sided colonic inflammation in patients with left-sided chronic ulcerative colitis. Inflamm Bowel Dis 10:215-219. https://doi.org/10.1097/00054725200405000-00006

62. Scott IS, Sheaff M, Coumbe A, Feakins RM, Rampton DS (1998) Appendiceal inflammation in ulcerative colitis. Histopathology 33:168-173. https://doi.org/10.1046/j.1365-2559.1998.00477.x

63. Odze R (2003) Diagnostic problems and advances in inflammatory bowel disease. Mod Pathol 16:347-358. https://doi.org/10. 1097/01.MP.0000064746.82024.D1

64. D'Haens G, Geboes K, Peeters M et al (1997) Patchy cecal inflammation associated with distal ulcerative colitis: a prospective endoscopic study. Am J Gastroenterol 92:1275-1279

65. Kroft SH, Stryker SJ, Rao MS (1994) Appendiceal involvement as a skip lesion in ulcerative colitis. Mod Pathol 7:912-914

66. Bernstein CN, Shanahan F, Anton PA, Weinstein WM (1995) Patchiness of mucosal inflammation in treated ulcerative colitis: a prospective study. Gastrointest Endosc 42:232-237. https://doi. org/10.1016/s0016-5107(95)70097-8

67. Geboes K (2001) Pathology of inflammatory bowel diseases (IBD): variability with time and treatment. Color Dis 3:2-12. https://doi.org/10.1046/j.1463-1318.2001.00187.x

68. Markowitz J, Kahn E, Grancher K, Hyams J, Treem W, Daum F (1993) Atypical rectosigmoid histology in children with newly diagnosed ulcerative colitis. Am J Gastroenterol 88:2034-2037

69. Robert ME, Tang L, Hao LM, Reyes-Mugica M (2004) Patterns of inflammation in mucosal biopsies of ulcerative colitis: perceived differences in pediatric populations are limited to children younger than 10 years. Am J Surg Pathol 28:183-189. https://doi. org/10.1097/00000478-200402000-00005

70. Tanaka M, Riddell RH (1990) The pathological diagnosis and differential diagnosis of Crohn's disease. Hepatogastroenterology 37:18-31

71. Marshall JK, Thabane M, Steinhart AH, Newman JR, Anand A, Irvine EJ, Cochrane IBD Group (2010) Rectal 5-aminosalicylic acid for induction of remission in ulcerative colitis. Cochrane Database Syst Rev 20:CD004115. https://doi.org/10.1002/ 14651858.CD004115.pub2

72. Lie MR, Kanis SL, Hansen BE et al (2014) Drug therapies for ulcerative proctitis: systematic review and meta-analysis. Inflamm Bowel Dis 20:2157-2178. https://doi.org/10.1097/MIB. 0000000000000141

73. Cohen RD, Dalal SR (2015) Systematic review: Rectal therapies for the treatment of distal forms of ulcerative colitis. Inflamm Bowel Dis 21:1719-1736. https://doi.org/10.1097/MIB. 0000000000000379

74. Geboes K, Dalle I (2002) Influence of treatment on morphological features of mucosal inflammation. Gut 50:iii37-iii42. https://doi. org/10.1136/gut.50.suppl_3.iii37

75. Mosli MH, Feagan BG, Sandborn WJ, D Haens G, Behling C, Kaplan K, Driman DK, Shackelton LM, Baker KA, MacDonald JK, Vandervoort MK, Geboes K, Levesque BG (2014) Histologic evaluation of ulcerative colitis: a systematic review of disease activity indices. Inflamm Bowel Dis 20(3):564-575. https://doi. org/10.1097/01.MIB.0000437986.00190.71

76. Odze R, Antonioli D, Peppercorn M, Goldman H (1993) Effect of topical 5-aminosalicylic acid (5-ASA) therapy on rectal mucosal biopsy morphology in chronic ulcerative colitis. Am J Surg Pathol 
27:869-875. https://doi.org/10.1097/00000478-19930900000002

77. Fournier BM, Parkos CA (2012) The role of neutrophils during intestinal inflammation. Mucosal Immunol 5(4):354-366. https:// doi.org/10.1038/mi.2012.24

78. Billioud V, Ford AC, Del Tedesco E et al (2013) Preoperative use of anti-TNF therapy and postoperative complications in inflammatory bowel diseases: a meta-analysis. J Crohn Colitis 7(11): 853-867. https://doi.org/10.1016/j.crohns.2013.01.014

79. Herfarth H, Tjaden C, Lukas M et al (2006) Adverse events in clinical trials with azathioprine and mesalamine for prevention of postoperative recurrence of Crohn's disease. Gut 55(10):15251526

80. D'Haens GR, Vermeire S, Van Assche G et al (2008) Therapy of metronidazole with azathioprine to prevent postoperative recurrence of Crohn's disease: a controlled randomized trial. Gastroenterology 135(4):1123-1129. https://doi.org/10.1053/j. gastro.2008.07.010

81. Nos P, Hinojosa J, Aguilera V, Moles JR et al (2000) Azathioprine and 5-ASA in the prevention of postoperative recurrence of Crohn's disease. Gastroenterol Hepatol 23(8):374-378

82. Reinisch W, Angelberger S, Petritsch W, Shonova O, Lukas M, Bar-Meir S, Teml A, Schaeffeler E, Schwab M, Dilger K, Greinwald R, Mueller R, Stange EF, Herrlinger KR, on behalf of the International AZT-2 Study Group (2010) Azathioprine versus mesalazine for prevention of postoperative clinical recurrence in patients with Crohn's disease with endoscopic recurrence: efficacy and safety results of a randomised, double-blind, doubledummy, multicentre trial. Gut 59(6):752-759. https://doi.org/10. 1136/gut.2009.194159

83. Peyrin-Biroulet L, Deltenre P, Ardizzone S, D'Haens G, Hanauer SB, Herfarth H, Lémann M, Colombel JF (2009) Azathioprine and 6-mercaptopurine for the prevention of postoperative recurrence in Crohn's disease: a meta-analysis. Am J Gastroenterol 104(8):2089-2096. https://doi.org/10.1038/ajg.2009.301

84. Regueiro M, Schraut W, Baidoo L, Kip KE, Sepulveda AR, Pesci M, Harrison J, Plevy SE (2009) Infliximab prevents Crohn's disease recurrence after ileal resection. Gastroenterology 136(2): 441-450. https://doi.org/10.1053/j.gastro.2008.10.051

85. Regueiro M, Baidoo L, Kip KE et al (2013) Infliximab maintenance beyond one year prevents postoperative Crohn's disease recurrence: long-term follow-up from the randomized controlled pilot study. Gastroenterology 144(5):S173-S17S

86. Yoshida K, Fukunaga K, Ikeuchi H, Kamikozuru K, Hida N, Ohda Y, Yokoyama Y, Iimuro M, Takeda N, Kato K, Kikuyama R, Nagase K, Hori K, Nakamura S, Miwa H, Matsumoto T (2012) Scheduled infliximab monotherapy to prevent recurrence of Crohn's disease following ileocolic or ileal resection: a 3-year prospective randomized open trial. Inflamm Bowel Dis 18(9):1617-1623. https://doi.org/10.1002/ibd.21928

87. Lin J, McKenna BJ, Appelman HD (2010) Morphologic findings in upper gastrointestinal biopsies of patients with ulcerative colitis: a controlled study. Am J Surg Pathol 34:1672-1677. https://doi. org/10.1097/PAS.0b013e3181f3de93

88. Castellaneta SP, Afzal NA, Greenberg M, Deere H, Davies S, Murch SH, Walker-Smith JA, Thomson M (2004) Diagnostic role of upper gastrointestinal endoscopy in pediatric inflammatory bowel disease. J Pediatr Gastroenterol Nutr 39(3):257-261. https://doi.org/10.1097/00005176-200409000-00006

89. Greuter T, Piller A, Fournier N et al (2018) Upper gastrointestinal tract involvement in Crohn's disease: frequency, risk factors, and disease course. J Crohns Colitis 12(12):1399-1409. https://doi. org/10.1093/ecco-jcc/jjy121

90. Oberhuber G, Püspök A, Oesterreicher C et al (1997) Focally enhanced gastritis: a frequent type of gastritis in patients with
Crohn's disease. Gastroenterology 112(3):698-706. https://doi. org/10.1053/gast.1997.v112.pm9041230

91. Wright CL, Riddell RH (1998) Histology of the stomach and duodenum in Crohn's disease. Am J Surg Pathol 22(4):383-390. https://doi.org/10.1097/00000478-199804000-00001

92. Cosnes J, Gower-Rousseau C, Seksik P et al (2011) Epidemiology and natural history of inflammatory bowel diseases. Gastroenterology 140:1785-1794. https://doi.org/10.1053/j. gastro.2011.01.055

93. Levine DS, Haggitt RC (1989) Normal histology of the colon. Am J Surg Pathol 13:966-984. https://doi.org/10.1097/00000478198911000-00008

94. Molodecky NA, Soon IS, Rabi DM, Ghali WA, Ferris M, Chernoff G, Benchimol EI, Panaccione R, Ghosh S, Barkema HW, Kaplan GG (2012) Increasing incidence and prevalence of the inflammatory bowel diseases with time, based on systematic review. Gastroenterology 142:46-54. https://doi.org/10.1053/j. gastro.2011.10.001

95. Burisch J, Pedersen N, Cukovic-Cavka S et al (2014) East-west gradient in the incidence of inflammatory bowel disease in Europe: the ECCO-EpiCom inception cohort. Gut 63:588-597. https://doi.org/10.1136/gutjnl-2013-304636

96. Lakatos L, Kiss LS, David G, Pandur T, Erdelyi Z, Mester G, Balogh M, Szipocs I, Molnar C, Komaromi E, Laszlo Lakatos P (2011) Incidence, disease phenotype at diagnosis, and early disease course in inflammatory bowel diseases in Western Hungary, 2002-2006. Inflamm Bowel Dis 17:2558-2265. https://doi.org/ 10.1002/ibd.21607

97. Shivananda S, Lennard-Jones J, Logan R, Fear N, Price A, Carpenter L, van Blankenstein M (1996) Incidence of inflammatory bowel disease across Europe: is there a difference between north and south? Results of the European Collaborative Study on Inflammatory Bowel Disease (EC-IBD). Gut 39:690-697. https:// doi.org/10.1136/gut.39.5.690

98. Björnsson S, Jóhannsson JH (2000) Inflammatory bowel disease in Iceland, 1990-1994: a prospective, nationwide, epidemiological study. Eur J Gastroenterol Hepatol 12:31-38. https://doi.org/ $10.1080 / 00365529850166239$

99. Vind L, Riis T, Jess E et al (2006) Increasing incidences of inflammatory bowel disease and decreasing surgery rates in Copenhagen City and County, 2003-2005: a population-based study from the Danish Crohn colitis database. Am J Gastroenterol 101:1274-1282. https://doi.org/10.1111/j.15720241.2006.00552.x

100. Langholz E, Munkholm P, Nielsen OH, Kreiner S, Binder V (1991) Incidence and prevalence of ulcerative colitis in Copenhagen county from 1962 to 1987 . Scand J Gastroenterol 26:1247-1256. https://doi.org/10.3109/00365529108998621

101. Moum B, Vatn MH, Ekbom A, Aadland E, Fausa O, Lygren I, Sauar J, Schulz T, Stray N (1996) Incidence of ulcerative colitis and indeterminate colitis in four counties of southeastern Norway, 1990-93. A prospective population-based study. The Inflammatory Bowel South-Eastern Norway (IBSEN) Study Group of Gastroenterologists. Scand J Gastroenterol 31:362366. https://doi.org/10.3109/00365529609006411

102. Geboes K, Colombel JF, Greenstein A, Jewell DP, Sandborn WJ, Vatn MH, Warren B, Riddell RH, Pathology Task Force of the International Organization of Inflammatory Bowel Diseases (2008) Indeterminate colitis: a review of the concept - what's in a name? Inflamm Bowel Dis 14:850-857. https://doi.org/10.1002/ ibd.20361

103. Bonetti LR, Manta R, Manno M et al (2018) Optimal processing of ESD specimens to avoid pathological artifacts. Tech Coloproctol 22:857-866. https://doi.org/10.1007/s10151-0181887-x 
104. Kim B, Barnett JL, Kleer CG, Appelman HD (1999) Endoscopic and histological patchiness in treated ulcerative colitis. Am J Gastroenterol 94:3258-3262. https://doi.org/10.1111/j.15720241.1999.01533.x

105. Gramlich T, Petras RE (2007) Pathology of inflammatory bowel disease. Semin Pediatr Surg 16:154-163. https://doi.org/10.1053/ j.sempedsurg.2007.04.005

106. Pai RK, Jairath V, Vande Casteele N, Rieder F, Parker CE, Lauwers GY (2018) The emerging role of histologic disease activity assessment in ulcerative colitis. Gastrointest Endosc 88: 887-898. https://doi.org/10.1016/j.gie.2018.08.018

107. Mosli MH, Feagan BG, Zou G, Sandborn WJ, D'Haens G, Khanna R, Behling C, Kaplan K, Driman DK, Shackelton LM, Baker KA, MacDonald JK, Vandervoort MK, Samaan MA, Geboes K, Valasek MA, Pai R, Langner C, Riddell R, Harpaz N, Sewitch M, Peterson M, Stitt LW, Levesque BG (2014) Reproducibility of histological assessment of disease activity in UC. Gut 64:1-9. https://doi.org/10.1136/gutjnl-2014-307536

108. Surawicz CM, Haggitt RC, Husseman M, McFarland LV (1994) Mucosal biopsy diagnosis of colitis: acute self-limited colitis and idiopathic inflammatory bowel disease. Gastroenterology 107 : 755-763. https://doi.org/10.1016/0016-5085(94)90124-4

109. Marchal-Bressenot A, Salleron J, Boulagnon-Rombi C, Bastien C, Cahn V, Cadiot G, Diebold MD, Danese S, Reinisch W, Schreiber S, Travis S, Peyrin-Biroulet L (2017) Development and validation of the Nancy histological index for UC. Gut 66:43-49. https://doi. org/10.1136/gutjnl-2015-310187

110. Rubio CA, Johansson C, Uribe A, Kock Y (1984) A quantitative method of estimating inflammation in the rectal mucosa. IV. Ulcerative colitis in remission. Scand J Gastroenterol 19:525-530

111. Sadik CD, Kim ND, Luster AD (2011) Neutrophils cascading their way to inflammation. Trends Immunol 32:452-460. https:// doi.org/10.1016/j.it.2011.06.008

112. Chin AC, Parkos CA (2007) Pathobiology of neutrophil transepithelial migration: implications in mediating epithelial injury. Annu Rev Pathol 2:111-143. https://doi.org/10.1146/ annurev.pathol.2.010506.091944

113. Pai RK, Hartman DJ, Rivers CR, Regueiro M, Schwartz M, Binion DG, Pai RK (2019) Complete resolution of mucosal neutrophils associates with improved long-term clinical outcomes of patients with ulcerative colitis. Clin Gastroenterol Hepatol 18(11):2510-2517. https://doi.org/10.1016/j.cgh.2019.12.011

114. Mosli MH, Feagan BG, Zou G, Sandborn WJ, D'Haens G, Khanna R, Shackelton LM, Walker CW, Nelson S, Vandervoort MK, Frisbie V, Samaan MA, Jairath V, Driman DK, Geboes K, Valasek MA, Pai RK, Lauwers GY, Riddell R, Stitt LW, Levesque BG (2017) Development and validation of a histological index for UC. Gut 66:50-58. https://doi.org/10.1136/gutjnl2015-310393

115. Bressenot A, Salleron J, Bastien C, Danese S, Boulagnon-Rombi C, Peyrin-Biroulet L (2015) Comparing histological activity indexes in UC. Gut 64(9):1412-1418. https://doi.org/10.1136/ gutjnl-2014-307477

116. Feagan BG, Greenberg GR, Wild G, Fedorak RN, Paré P, McDonald JWD, Dubé R, Cohen A, Steinhart AH, Landau S, Aguzzi RA, Fox IH, Vandervoort MK (2005) Treatment of ulcerative colitis with a humanized antibody to the alpha4beta7 integrin. New Engl J Med 352(4):2499-2507. https://doi.org/10. 1056/NEJMoa042982

117. Targan SR, Karp LC (2007) Inflammatory bowel disease diagnosis, evaluation and classification: state-of-the art approach. Curr Opin Gastroenterol 23:390-394. https://doi.org/10.1097/MOG. 0b013e3281722271

118. Engel MA, Neurath MF (2010) New pathophysiological insights and modern treatment of IBD. J Gastroenterol 45:571-583. https:// doi.org/10.1007/s00535-010-0219-3

119. Ng SC, Kamm MA (2009) Therapeutic strategies for the management of ulcerative colitis. Inflamm Bowel Dis 15:935-950. https:// doi.org/10.1002/ibd.20797

120. Christensen B, Erlich J, Gibson PR, Turner JR, Hart J, Rubin DT (2020) Histologic healing is more strongly associated with clinical outcomes in ileal Crohn's disease than endoscopic healing. Clin Gastroenterol Hepatol 18:2518-2525. https://doi.org/10.1016/ jcgh.2020.01.032

Publisher's note Springer Nature remains neutral with regard to jurisdictional claims in published maps and institutional affiliations.

\section{Affiliations}

\section{Corinna Lang-Schwarz ${ }^{1} \cdot$ Abbas Agaimy $^{2} \cdot$ Raja Atreya $^{3,4} \cdot$ Christoph Becker $^{3,4} \cdot$ Silvio Danese $^{5}$ • Jean-François Fléjou ${ }^{6}$. Nikolaus Gaßler ${ }^{7}$. Heike I. Grabsch ${ }^{8,9} \cdot$ Arndt Hartmann $^{2}$ • Kateřina Kamarádová ${ }^{10}$ - Anja A. Kühl ${ }^{4,11}$. Gregory Y. Lauwers ${ }^{12}$. Alessandro Lugli ${ }^{13}$ - Iris Nagtegaal ${ }^{14}$. Markus F. Neurath ${ }^{3,4}$. Georg Oberhuber ${ }^{15}$. Laurent Peyrin-Biroulet ${ }^{16} \cdot$ Timo Rath $^{3} \cdot$ Robert Riddell $^{17}$. Carlos A. Rubio ${ }^{18} \cdot$ Kieran Sheahan $^{19} \cdot$ Herbert Tilg $^{20}$. Vincenzo Villanacci ${ }^{21} \cdot$ Maria Westerhoff ${ }^{22} \cdot$ Michael Vieth $^{1,2}$}

1 Institute of Pathology, Klinikum Bayreuth GmbH, Preuschwitzer Str. 101, 95445 Bayreuth, Germany

2 Institute of Pathology, Friedrich-Alexander University, Erlangen, Germany

3 Medical Clinic 1, Department of Medicine \& Deutsches Zentrum Immuntherapie DZI, University Hospital, Friedrich-Alexander University, Erlangen, Germany

4 The Transregio 241 IBDome Consortium, Erlangen, Germany

5 Department of Gastroenterology, IBD Centre, Humanitas Research Hospital, Via A. Manzoni 56, 20089 Rozzano, Milan, Italy
6 Pathology Department, Saint-Antoine Hospital, APHP, Sorbonne University, Paris, France

7 Institute for Legal Medicine, Section Pathology, University Hospital, Jena, Germany

8 Department of Pathology, GROW - School for Oncology and Developmental Biology, Maastricht University Medical Center, Maastricht, The Netherlands

9 Pathology and Data Analytics, Leeds Institute of Medical Research at St James's, University of Leeds, Leeds, UK 
10 The Fingerland Department of Pathology, Faculty of Medicine and University Hospital, Charles University, Hradec Králové, Czech Republic

11 Charité-Universitätsmedizin Berlin, Corporate Member of Freie Universität Berlin, Humboldt-Universität zu Berlin and Berlin Institute of Health, iPATH.Berlin, Campus Benjamin Franklin, Hindenburgdamm 30, 12200 Berlin, Germany

Department of Pathology, Moffitt Cancer Center, Tampa, FL, USA

13 Institute of Pathology, University of Bern, Bern, Switzerland

14 Department of Pathology, Radboud University Medical Centre, Nijmegen, The Netherlands

15 INNPATH, Institute of Pathology, Tirol Kliniken, Innsbruck, Austria \& Patho im Zentrum, St. Pölten, Austria

16 Department of Gastroenterology, Nancy University Hospital, Vandoeuvre, France \& Inserm U1256, Lorraine University, Vandoeuvre, France
17 Pathology and Laboratory Medicine, Mount Sinai Hospital, University of Toronto, Toronto, ON, Canada

18 Department of Pathology, Karolinska Institute and University Hospital, Stockholm, Sweden

19 Department of Pathology \& Centre for Colorectal Disease, St Vincent's University Hospital \& University College, Dublin, Ireland

Department of Internal Medicine I, Gastroenterology, Hepatology, Endocrinology and Metabolism, Medical University Innsbruck, Innsbruck, Austria

21 Department of Pathology, Spedali Civili di Brescia, Brescia, Italy

22 Department of Pathology, University of Michigan, Ann Arbor, MI, USA 